\title{
Ustalenie danych osobowych sprawcy naruszenia dóbr osobistych w Internecie celem dochodzenia ich ochrony w postępowaniu cywilnym
}

Dowszechny dostęp do Internetu przyniósł wiele społecznych korzyści, ma jednak swoje negatywne konsekwencje. Badania A. Flores i C. James dowiodły, że internauci funkcjonując $\mathrm{w}$ przestrzeni wirtualnej, charakteryzują się myśleniem egoistycznym $\mathrm{i}$ indywidualistycznym ${ }^{1}$. Z uwagi na poczucie anonimowości, które daje Internet, część użytkowników pozwala sobie na zachowania naruszające dobre imię innych użytkowników (często są to wypowiedzi obraźliwe, nie mające $\mathrm{z}$ reguły merytorycznego uzasadnienia, określane potocznie mianem „hejtu”) i zdarza się, że nie ponoszą oni z tego tytułu odpowiedzialności. Wprawdzie w praktyce wskazuje się, że tego rodzaju wypowiedzi jest stosunkowo mało, lecz mimo to stanowią one nie tylko o istniejącym problemie społecznym, ale przede wszystkim mają swoje implikacje prawne ${ }^{2}$.

\footnotetext{
* Dr Piotr F. Piesiewicz - adiunkt na Wydziale Prawa SWPS Uniwersytetu Humanistycznospołecznego SWPS, w Katedrze Prawa Ochrony Własności Intelektualnej, adwokat; e-mail: ppiesiewicz@ swps.edu.pl.

** Dr Olga M. PIaskowska - adiunkt na Wydziale Prawa SWPS Uniwersytetu Humanistycznospołecznego SWPS, w Katedrze Prawa Cywilnego i Prawa Pracy, starszy asystent sędziego w Izbie Cywilnej Sądu Najwyższego; e-mail: opiaskowska@swps.edu.pl.

${ }^{1}$ A. Flores, C. James, Morality and ethics behind the screen: Young people's perspectives on digital life (w:) New Media \& Society, Volume: 15 issue: 6, s. 834-852, September 1, 2013 https://doi. org/10.1177/1461444812462842

${ }^{2}$ Zob. Ł. Jonak, Dlaczego boimy się jednego procenta? O braku agresji w Internecie, [w:] Internetowa kultura obrażania?, K. Krejtz (red.), Interactive Advertising Bureau Polska, Szkoła Wyższa Psychologii Społecznej oraz Ośrodek Przetwarzania Informacji, s. 57-66, http://komentuj-nie-obrazaj. pl/media/KOraport.pdf, dostęp 30112017.
} 
Przedmiotem rozważań podjętych w niniejszym artykule jest problematyka prawna związana $\mathrm{z}$ możliwością dochodzenia roszczenia $\mathrm{z}$ tytułu naruszenia dóbr osobistych w Internecie przez osobę dotkniętą naruszeniem, z perspektywy konieczności ustalenia przez stronę dochodzącą praw danych osobowych naruszyciela. Z tego też względu w artykule odwołano się także do propozycji pozwu anonimowego zawartego w projekcie zmiany ustawy Kodeks postępowania cywilnego oraz ustawy Prawo telekomunikacyjne ${ }^{3}$. Wprawdzie projekt ustawy został odrzucony w pierwszym czytaniu (na posiedzeniu nr 48 dnia 29 września $2017 \mathrm{r}^{4}$ ), jednakże stanowił interesujący głos w dyskusji nad wskazanym zagadnieniem.

Omówienie tak zakreślonej problematyki wymaga w pierwszej kolejności odniesienia się do kwestii naruszenia dóbr osobistych w Internecie, a następnie wskazania kręgu podmiotów, które za wskazane naruszenia mogą w świetle obecnych rozwiązań ponieść odpowiedzialność, i ewentualnie na jakiej podstawie. W dalszej kolejności należy odnieść się do problematyki związanej z ustaleniem danych niezbędnych dla identyfikacji tych podmiotów oraz sposobu, w jaki dane te można uzyskać. Poruszone w powyższym zakresie kwestie pozwolą na udzielenie odpowiedzi na pytanie, czy prawa osób, których dobra osobiste zostały naruszone poprzez wpisy internetowe są realnie chronione, czy też i ewentualnie, $z$ jakich względów ochrona ta może być iluzoryczna. W ramach tych rozważań, zostanie podjęta problematyka związana z propozycjami zmian, o których wspomniano powyżej, a przede wszystkim instytucji pozwu anonimowego, w kontekście celu, jaki postawili sobie projektodawcy zmian, a który pozostaje zbieżny z tezami niniejszego artykułu.

Problematyce naruszania dóbr osobistych w Internecie poświęcono stosunkowo dużo uwagi, zarówno w orzecznictwie, jak i doktrynie. Naruszenie dóbr osobistych, których otwarty katalog znajduje się w art. 23 k.c., prowadzić powinno do zrekompensowania osobie dotkniętej naruszeniem, doznanej przez nią krzywdy. W razie dokonanego naruszenia można także żądać, aby osoba, która dopuściła się naruszenia, dopełniła czynności potrzebnych do usunięcia jego skutków, w szczególności ażeby złożyła oświadczenie odpowiedniej treści i w odpowiedniej formie. Ponadto na zasadach przewidzianych w kodeksie cywilnym pokrzywdzony może również żądać zadośćuczynienia pieniężnego lub zapłaty odpowiedniej sumy pieniężnej na wskazany cel społeczny (art. 24 k.c.). Ten ostatni zapis konkretyzuje art. 448 k.c., zgodnie z którym w razie naruszenia dobra osobistego sąd może przyznać temu, czyje dobro osobiste zostało naruszone, odpowiednią sumę tytułem zadośćuczynienia pieniężnego za doznaną krzywdę lub na jego żądanie zasądzić odpowiednią sumę pieniężną na wskazany

${ }^{3}$ Druk Sejmu VIII Kadencji Nr 1715.

${ }^{4} \mathrm{Za}$ odrzuceniem głosowało 252 posłów, 172 przeciw, 8 wstrzymało się. 
przez niego cel społeczny. Warto przy tym zwrócić uwagę na fakt, że dobra osobiste, jako wartości związane $\mathrm{z}$ wewnętrzną stroną życia ludzi ${ }^{5}$, podlegają ochronie konstytucyjnej, a także ochronie nie tylko na gruncie prawa cywilnego, a zatem $\mathrm{w}$ kontekście dochodzenia roszczeń $\mathrm{z}$ art. 24 k.c., ale także na gruncie prawa karnego, gdzie pokrzywdzony także może żądać ukarania sprawcy (art. 212 k.k.). Ta konstatacja nie pozostaje bez znaczenia dla dalszych rozważań, pomimo iż zakres kognicji organów karnych znacznie różni się od tego, co pozostaje w zakresie kognicji sądów cywilnych. Należy jednakże pamiętać, że u źródła oceny (czy to cywilnoprawnej, czy prawnokarnej) tkwi to samo zdarzenie oraz udziałem tych samych podmiotów.

Naruszenie dóbr osobistych w Internecie może mieć różną formę, tj. np.: spamming będący zagrożeniem sfery prywatnej osoby fizycznej korzystającej z poczty elektronicznej ${ }^{6}$, czy cookies, które ułatwiają śledzenie użytkownika w sieci. Wymienione formy, a także wiele innych ${ }^{7}$, stanowią naruszenie prawa użytkownika do prywatności i bardzo często nie są przez niego samego traktowane jako krzywdzące, czy dotkliwe. Sytuacja kształtuje się jednak inaczej $\mathrm{w}$ przypadku zamieszczenia na portalu, forum internetowym komentarza naruszającego wprost dobre imię osoby trzeciej. Taki wpis może oczywiście pozostać przez osobę trzecią niezauważony, a w konsekwencji nie dowie się ona o naruszeniu jej czci, godności, i w takiej sytuacji nie będzie ona dochodzić swoich praw. W przypadku jednak wykrycia naruszenia oraz będącej jego następstwem chęci dochodzenia swoich praw, konieczne jest zidentyfikowanie osoby kryjącej się pod pseudonimem, ewentualnie - w zależności od sytuacji ustalenia, jakie inne podmioty mogą zostać pociągnięte do odpowiedzialności za wskazane naruszenie.

Podejmowana w doktrynie problematyka naruszenia dóbr osobistych w Internecie jest wielowątkowa. Wielość wątków pojawiających się w odniesieniu do tej problematyki wynika m.in. z szeregu regulacji ustawowych, które mając na uwadze określony stan faktyczny - będą mogły znaleźć zastosowanie w sprawie, a w szczególności w odniesieniu do kwestii wskazania podmiotu odpowiedzialnego za opublikowane w Internecie treści naruszające dobra osobiste osób trzecich. Trzeba bowiem wyraźnie zaznaczyć, że odpowiedzialność tę nie zawsze ponosi jedynie ten podmiot, który swoim działaniem (sformułowaniem i opublikowaniem określonej treści) dopuścił się naruszenia. Należy bowiem zwrócić uwagę na fakt, że przepis art. $24 \$ 1$ k.c. (regulujący roszczenia osoby

${ }^{5}$ Zob. wyrok SN z dnia 19 września 1968 r., II CR 291/68, OSNC 1969, Nr 11, poz. 200.

${ }^{6}$ Zob. m.in. P. Waglowski, Spam a prawo. Próba wskazania kierunków badawczych, „Prawo i Ekonomia w Telekomunikacji” 2003, nr 4, s. 62; A. Rogacka-Łukasik, Naruszenie dóbr osobistych w internecie oraz ich ochrona na podstawie ustawy o świadczeniu usług drogą elektroniczna, Roczniki Administracji i Prawa. Teoria i Praktyka, ROK XII, Sosnowiec 2012, s. 237.

7 Zob. A. Rogacka-Łukasik, Naruszenie dóbr osobistych..., s. 237 i nast. 
dotkniętej naruszeniem) nie ogranicza jego zastosowania do bezpośrednich sprawców naruszenia, ale obejmuje swoim zakresem wszelkie działania określonego podmiotu, które w jakikolwiek sposób powodują, czy przyczyniają się do naruszenie dóbr osobistych poszkodowanego lub do pogłębienia naruszeń tych dóbr, dokonanych uprzednio przez inne podmioty ${ }^{8}$. Określając krąg podmiotów, które w danej sytuacji mogą ponieść odpowiedzialność za naruszenie dóbr osobistych w Internecie, w tym także za umieszczony przez użytkownika komentarz na portalu internetowym, należy wskazać na przepisy ustawy z dnia 18 lipca 2002 r. o świadczeniu usług drogą elektroniczną ${ }^{9}$ (art. 14) oraz przepisy ustawy z dnia 26 stycznia 1984 r. Prawo prasowe ${ }^{10}$ (art. 38). Pierwszy z przywołanych przepisów odnosi się do odpowiedzialności service providera i stanowi podstawę wyłączenia jego odpowiedzialności za przechowywane dane, jeżeli udostępniając zasoby systemu teleinformatycznego w celu przechowywania danych przez usługobiorcę nie wie o bezprawnym charakterze danych lub związanej z nimi działalności, a w razie otrzymania urzędowego zawiadomienia lub uzyskania wiarygodnej wiadomości o bezprawnym charakterze danych lub związanej z nimi działalności niezwłocznie uniemożliwi dostęp do tych danych. Z kolei art. 38 pr. pras. stanowi o odpowiedzialności cywilnej za naruszenie spowodowane opublikowaniem materiału prasowego, którą ponoszą autor, redaktor lub inna osoba, którzy spowodowali opublikowanie tego materiału; powyższe nie wyłącza odpowiedzialności wydawcy. Ustalenie danych podmiotu odpowiedzialnego w świetle przytoczonych powyżej przepisów, co do zasady, nie nastręcza trudności. Inaczej jest jednak w przypadku osoby będącej rzeczywistym sprawcą naruszenia, a mianowicie nie ulega wątpliwości, że wielokrotnie istnieje trudność w ustaleniu, kto kryje się pod internetowym pseudonimem. W konsekwencji, w obecnym stanie prawnym, przekłada się to na możliwość dochodzenia na drodze postępowania cywilnego zadośćuczynienia od bezpośredniego sprawcy naruszenia dobra osobistego. Trzeba przy tym wyraźnie zaznaczyć, że odnosi się do jedynie do tych sytuacji, w których danego komentarza nie można zakwalifikować jako materiału prasowego, albowiem taka jego kwalifikacja pozwala stronie dotkniętej naruszeniem, na dochodzenie swoich praw w oparciu o przepisy ustawy Prawo prasowe ${ }^{11}$. Powyższe uwagi prowadzą do konstatacji, że odpowiedzialność za naruszenie dóbr osobistych mogą więc ponieść inne podmioty, aniżeli bezpośredni sprawca naruszenia, a jednocześnie ich identyfikacja jest stosunkowo prosta. Jak wskazano wyżej, inaczej sytuacja kształtuje się wówczas, gdy osoba dotknięta naruszeniem może

8 Zob. m.in. wyrok Sądu Najwyższego z dnia 30 września 2016 r., I CSK 598/15, LEX nr 2151458.

9 T.j. Dz.U. 2017, Nr 1219.

${ }_{10}$ Dz.U. 1984, Nr 5, poz. 24 ze zm.

${ }^{11} \mathrm{~W}$ tym kontekście należy wskazać na treść art. 15 ust. 1 Prawa prasowego, który stanowi, że Autorowi materiału prasowego przysługuje prawo zachowania w tajemnicy swego nazwiska. 
dochodzić swoich praw jedynie wobec bezpośredniego sprawcy naruszenia, a zatem dysponuje - $\mathrm{w}$ momencie powzięcia informacji o naruszeniu jedynie pseudonimem, którym posłużył się sprawca. Chcąc jednak wystąpić z powództwem $z$ tytułu naruszenia dóbr osobistych musi jednakże dysponować pełnymi danymi sprawcy naruszenia.

W obecnym kształcie, przepisy Kodeksu postępowania cywilnego przewidują bowiem, że pozwanym w sprawie może być tylko podmiot zidentyfikowany, zarówno z imienia, jak i nazwiska, a ponadto obowiązkiem powoda jest wskazanie adresu pozwanego, pod który należy doręczać mu pisma procesowe. Wykonanie tego obowiązku, wynikającego z art. $126 \$ 1$ w zw. z art. $187 \S 1$ k.p.c., wymaga zatem od powoda (w tym przypadku osoby, której dobra osobiste zostały naruszone), przed wytoczeniem powództwa, podjęcia działań zmierzających do samodzielnego ustalenia danych osobowych i adresowych sprawcy naruszenia. Niewskazanie pozwanego $z$ imienia i nazwiska oraz jego adresu prowadzi bowiem do zwrotu pozwu (art. 130 k.p.c.).

Ustalenie danych osobowych sprawcy naruszenia dóbr osobistych w Internecie jest możliwe przede wszystkim na podstawie cytowanej wyżej ustawy z dnia 18 lipca 2002 r. o świadczeniu usług drogą elektroniczną ${ }^{12}$.

Stosownie do treści art. 18 ust. 6 u.o.ś.d.e. ustawy usługodawca nieodpłatnie udostępnia dane, o których mowa w ust. 1-5, organom państwa uprawnionym na podstawie odrębnych przepisów na potrzeby prowadzonych przez nie postępowań. Zwrócić należy przy tym uwagę, że literalne brzmienie przywołanego przepisu wskazuje na uprawnienie do udzielenia danych uprawnionym "organom państwa" na potrzeby prowadzonych przez nie postępowań. Strona chcąca dochodzić swoich praw, z uwagi na naruszenie przez użytkownika sieci jej dobrego imienia, nie została zatem $w$ tym przepisie wskazana jako podmiot uprawniony. $Z$ czego można wyprowadzić wniosek, że osoby prywatne nie są upoważnione do otrzymania takich danych, w oparciu o stosowny wniosek skierowany do service providera. Trzeba jednak zauważyć, że kwestia ta nie jest rozstrzygana jednolicie.

Omawiając tę kwestię należy zwrócić uwagę, że problematyka udostępniania danych osobom prywatnym na potrzeby postępowań cywilnych była przedmiotem rozważań Europejskiego Trybunału Sprawiedliwości. Stanowisko to jest dla potrzeb niniejszych rozważań o tyle istotne, że ustawa z dnia 18 lipca $2002 \mathrm{r}$. o świadczeniu usług drogą elektroniczną, stanowi implementację dyrektywy 2000/31/WE Parlamentu Europejskiego i Rady z dnia 8 czerwca 2000 r. w sprawie niektórych aspektów prawnych usług społeczeństwa informacyjnego, w szczególności handlu elektronicznego w ramach rynku wewnętrznego (dyrektywa

12 t.j. Dz.U. 2017, poz. 1219, dalej: u.ś.u.e. 
o handlu elektronicznym) ${ }^{13}$. W wyroku $\mathrm{z}$ dnia 29 stycznia $2008 \mathrm{r}^{14}$ oraz w postanowieniu z dnia 19 lutego 2009 r. ${ }^{15}$, ETS dokonał analizy przepisów dyrektywy, a w szczególności art. 13 ust. 1 dyrektywy 95/46/WE oraz art. 15 ust. 1 dyrektywy 2002/58/WE, w kontekście obowiązków dostawców usług, a konkretnie dostawców dostępu do Internetu ${ }^{16}$. Trybunał stwierdził, że z przepisów unijnych nie wynika wprowadzenie obowiązku przekazywania danych osobowych w celu zapewnienia skutecznej ochrony, w omawianych przypadkach praw autorskich, $\mathrm{w}$ postępowaniu cywilnym, aczkolwiek w procesie implementacji dyrektyw oraz stosowania prawa krajowego należy uwzględnić konieczność zapewnienia równowagi pomiędzy ochroną różnych praw podstawowych. W przypadku rozpoznawanych przez ETS było to prawo do poszanowania życia prywatnego oraz prawo własności i prawo do skutecznego środka prawnego. W przypadku naruszenia dóbr osobistych osoby trzeciej przez sprawcę ukrytego pod pseudonimem i wniosku osoby trzeciej o ujawnienie danych osobowych naruszyciela może dojść do kolizji pomiędzy prawem do poszanowania życia prywatnego i prawa do poszanowania czci (dobrego imienia i godności).

Kolizja dóbr w każdej sytuacji powoduje konieczność rozważenia, w odniesieniu do okoliczności konkretnego przypadku, któremu $\mathrm{z}$ tych dóbr można przyznać pierwszeństwo. $Z$ zasady bowiem są one równe, a więc żadne nie korzysta z pierwszeństwa. Warto przytoczyć jednakże w tym miejscu stanowisko wyrażone przez Sądu Apelacyjny w Krakowie, w którym wskazano, że "godność osobista przysługuje każdej osobie i podlega ochronie prawnej niezależnie od tego, w jaki sposób kształtuje się obraz danej osoby w opinii innych. O przyznaniu takiej ochrony rozstrzyga $z$ normatywnego punktu widzenia - uznanie podmiotowości każdego człowieka, z aksjologicznego zaś punktu widzenia - fundamentalny postulat poszanowania w każdym człowieku jego osoby ludzkiej. Również osobom, które dopuszczają się naruszenia porządku prawnego i moralnego przysługuje ochrona $w$ razie bezprawnej ingerencji w ich godność osobistą"17. Odnosząc się do kolizji wskazanych wyżej dóbr w kontekście omawianego przypadku, tj. naruszenia dóbr osobistych osoby trzeciej poprzez anonimowy wpis, zwrócić należy także uwagę na treść art. 5 k.c. W myśl tego przepisu nie można czynić ze swego prawa użytku, który byłby sprzeczny ze społeczno-gospodarczym przeznaczeniem tego prawa lub z zasadami współżycia

\footnotetext{
13 Dziennik Urzędowy L 178, 17/07/2000 P. 0001 - 0016.

${ }_{14}$ Wyrok ETS z dnia 29 stycznia 2008 r., w sprawie Productores de Música de España (Promusicae) przeciwko Telefónica de. España SAU, C-275/06, Zb.Orz. (2008) I-271.

15 Postanowienie ETS z dnia 19 lutego 2009 r. w sprawie LSG a Tele Telecommunication GmbH, C-557/07, ECR Zb. Orz. (2009) I-01227.

${ }_{16}$ W sprawie Promusicae również art. 15 i 18 ust. 1 dyrektywy 2000/31/WE.

17 Zob. wyrok Sądu Apelacyjnego w Krakowie z dnia 21 marca 1995 r., I ACr 113/95 (w:) Dobra osobiste. Zbiór, wkładka 1995, Nr 3, poz. 22.
} 
społecznego. Takie działanie lub zaniechanie nie jest uważane za wykonywanie prawa i nie korzysta $\mathrm{z}$ ochrony. $\mathrm{W}$ doktrynie wskazuje się, że przywołany przepis odnieść należy także do osobistych praw podmiotowych ${ }^{18}$. W tym kontekście kolizję wskazanych dóbr należałoby zatem rozstrzygnąć na korzyść osoby pokrzywdzonej, tj. której dobra zostały naruszone anonimowym wpisem. Konstatacja ta pozostaje w zgodności ze stanowiskiem Europejskiego Trybunału Sprawiedliwości, który wskazał w wyroku z dnia 19 kwietnia 2012 r., że przy transpozycji tych dyrektyw państwa członkowskie muszą bowiem opierać się na takiej wykładni tych dyrektyw, która pozwoli na zapewnienie odpowiedniej równowagi między poszczególnymi prawami podstawowymi chronionymi przez porządek prawny Unii Europejskiej. Następnie, przy przyjmowaniu środków mających na celu transpozycję tych dyrektyw władze i sądy państw członkowskich są zobowiązane nie tylko dokonywać wykładni swojego prawa krajowego w sposób zgodny ze wspomnianymi dyrektywami, lecz również uważać, by nie oprzeć się na takiej wykładni tych dyrektyw, która pozostawałaby w konflikcie z prawami podstawowymi lub z innymi ogólnymi zasadami prawa Unii, takimi jak zasada proporcjonalności ${ }^{19}$.

Stwierdzić jednak należy, że w praktyce kolizję tę na wstępie rozstrzyga usługodawca, a zatem najczęściej podmiot prywatny, któremu w razie naruszenia obowiązków nałożonych nie tylko przez ustawę o świadczeniu usług drogą elektroniczną, ale także rozporządzenie Parlamentu Europejskiego i Rady (UE) 2016/679 z dnia 27 kwietnia 2016 r. w sprawie ochrony osób fizycznych w związku z przetwarzaniem danych osobowych i w sprawie swobodnego przepływu takich danych oraz uchylenia dyrektywy 95/46/WE (ogólne rozporządzenie o ochronie danych) ${ }^{20}$ grożą przewidziane w tych aktach sankcje. Powyższe uwagi pozwalają na stwierdzenie, że w razie złożenia przez osobę prywatną wniosku o udostępnienie takich danych, otrzyma ona odpowiedź negatywną. Sprzyja temu także literalne brzmienie art. 18 ust. 6 u.ś.u.d.e.

W doktrynie wskazuje się, że z literalnego brzmienia wynika jasno, iż w art. 18 ust. 6 u.ś.u.d.e. przewidziano jedynie obowiązek udostępniania danych osobowych organom państwa ${ }^{21}$. W orzecznictwie jednakże prezentuje się także pogląd przeciwny. Wskazuje się bowiem, że przepis ten, stanowiący literalnie

${ }_{18}$ Zob. m.in. A. Szpunar, Ochrona dóbr osobistych, PWN Warszawa 1979, s. 139; tenże, Stosowanie art. 5 kodeksu cywilnego w sprawach o prawa stanu, PiP 1981, Nr 6, s. 47; T. Justyński, Nadużycie prawa w polskim prawie cywilnym, Kraków 2000, s. 69.

${ }_{19}$ Wyrok ETS z dnia 19 kwietnia 2012 r., w sprawie Bonnier Audio AB i inni przeciwko Perfect Communication Sweden AB, C-461/10, Lex 1131310.

${ }^{20}$ Dz. U. UE. L. z 2016 r. Nr 119, s. 1 z późn. zm.: dalej jako RODO.

${ }^{21}$ K. Klafkowska-Waśniowska, Komentarz do art. 18 ustawy o świadczeniu usług droga elektroniczną, (w:) D. Lubasz (red.), M. Namysłowska (red.), W. Chomiczewski, K. Klafkowska-Waśniowska, Świadczenie usług drogą elektroniczną oraz dostęp warunkowy. Komentarz do ustawy, LexisNexis 2011, Lex nr 334468. 
o obowiązku usługodawcy udzielania informacji o danych tamże określonych organom państwa na potrzeby prowadzonych przez nie postępowań, należy interpretować jako dopuszczający przetwarzanie danych osobowych przez wszystkie podmioty, gdy jest to niezbędne dla zrealizowania ich uprawnienia lub spełnienia obowiązku wynikającego z przepisu prawa. Nie został on zawężony do organów państwa, skoro nie posłużono się zwrotem „wyłącznie”, a istnieje potrzeba poszerzenia zakresu podmiotowego tego przepisu. $Z$ tego też względu udostępnienie spornych danych osobowych znajduje oparcie w przepisie art. 6 lit. f RODO dopuszczający to, gdy jest to niezbędne dla wypełnienia prawnie usprawiedliwionych celów realizowanych przez administratora danych osobowych albo odbiorcę danych, a przetwarzanie nie narusza praw i wolności osoby, której dane dotyczą ${ }^{22}$. Jest to konkluzja zgodna także ze stanowiskiem zajmowanym przez Europejski Trybunał Sprawiedliwości ${ }^{23}$.

Oznacza to, że ustalenie danych osobowych sprawcy naruszenia możliwe jest poprzez przekazanie danych osobowych takich użytkowników przez dostawców usług internetowych, co często jednakże powoduje wątpliwości, co do zgodności tych działań z prawem do prywatności oraz ochrony danych osobowych tych podmiotów ${ }^{24}$. Fakt istnienia takiej rozbieżności w interpretacji art. 18 ust. 6 u.ś.u.d.e., której rozstrzygnięcie nie jest jednakże konieczne dla potrzeb niniejszego artykułu, prowadzi do konstatacji, że uzyskanie danych osobowych bezpośredniego sprawcy naruszenia jest co najmniej wielce utrudnione. Złożenie przez osobę, której prawa zostały naruszone wniosku o udostępnienia danych naruszyciela kryjącego się pod pseudonimem, nie w każdej sytuacji będzie prowadzić do ich otrzymania. Zestawiając zaś tę trudność z faktem, iż w postępowaniu cywilnym, obowiązkiem powoda jest wskazanie nie tylko danych osobowych, ale i adresowych pozwanego, można postawić tezę, że w wielu przypadkach ochrona $z$ art. 24 k.c. pozostać może jedynie iluzoryczna. Zauważając przy tym, że poszkodowanemu naruszeniem biegnie termin przedawnienia na dochodzenie swoich roszczeń, może on finalnie nie otrzymać np. należnego mu odszkodowania.

Trudność w uzyskaniu danych osobowych sprawcy naruszenia dóbr osobistych przez pokrzywdzonego, $w$ praktyce prowadzi do inicjowania przez te podmioty postępowania karnego. Tak jak już wyżej zaznaczono, dobra osobiste

${ }^{22}$ Zob. także wyrok Naczelnego Sądu Administracyjnego w Warszawie z dnia 10 listopada 2015 r., I OSK 685/14, LEX nr 1989980. Takie też stanowisko zajął Naczelny Sąd Administracyjny w wyrokach z dnia: 21 sierpnia 2013 r., I OSK 1666/12, LEX nr 1391700 oraz z dnia 13 lutego 2014 r., I OSK 1641/12, LEX nr 149727.

${ }^{23}$ Zob. np.: wyrok ETS z dnia 19 kwietnia 2012 r., w sprawie Bonnier Audio AB i inni przeciwko Perfect Communication Sweden AB, C-461/10, Lex 1131310.

${ }_{24}$ Zob. także A. Kuźnicka, Egzekwowanie prawa autorskiego w Internecie a ochrona danych osobowych użytkowników, ZNUJ 2010, Nr 110, s. 109. 
podlegają nie tylko ochronie na gruncie prawa cywilnego, ale także na gruncie prawa karnego. Wskazać należy, że w myśl art. 212 k.k. kto pomawia inną osobę, grupę osób, instytucję, osobę prawną lub jednostkę organizacyjną niemającą osobowości prawnej o takie postępowanie lub właściwości, które mogą poniżyć ją w opinii publicznej lub narazić na utratę zaufania potrzebnego dla danego stanowiska, zawodu lub rodzaju działalności, podlega grzywnie albo karze ograniczenia wolności. Przedmiotem ochrony przepisu art. $212 \$ 1$ k.k. jest cześć i godność osoby pomawianej o postępowanie lub właściwości, które są sprzeczne z prawem, z zasadami etyki, w tym etyki zawodowej, oraz np. o brak kompetencji lub zdolności do wykonywania danego zawodu ${ }^{25}$. Wartość w postaci przedmiotu ochrony pozostawać powinna oczywiście w równowadze z koniecznością ochrony innych wartości, to jest prawa do swobody wypowiedzi, prawa do krytyki oraz możliwości działania różnych organów, których zadaniem jest między innymi ocena przydatności do wykonywania zawodu, w postaci weryfikacji kompetencji i zdolności oraz ocena kwalifikacji etycznych niezbędnych do zajmowania określonych stanowisk, wykonywania różnych zawodów lub prowadzenia określonego rodzaju działalności. (...) Prawo do „krytyki” nie może być utożsamiane z prawem do „zniesławiania”, a krytyczne oceny powinny być wyrażane w odpowiedniej formie, zwłaszcza gdy nie są wyrażane w sposób spontaniczny lub w toku szybkiej wymiany słów, a w sposób zaplanowany i przemyślany ${ }^{26}$. Tak bowiem, jak każdy człowiek ma prawo do wolności wyrażania opinii, tak również każdy człowiek ma prawo do poszanowania swojego życia prywatnego i rodzinnego, a prawo do wolności wyrażania opinii zasadnie może podlegać ograniczeniom ze względu m.in. na ochronę dobrego imienia i praw innych osób ${ }^{27}$. Przedmiotem ochrony w art. 212 k.k. jest zatem cześć, a zatem dobro osobiste podlegające ochronie także na podstawie art. 23 i 24 k.c. Inicjowanie postępowania karnego ma nie zawsze na celu ściganie sprawcy celem pociągnięcia go do odpowiedzialności karnej za dokonane naruszenie, stanowiące także przestępstwo z art. 212 k.k. Droga postępowania karnego jest bowiem często wykorzystywana jako łatwiejszy i szybszy sposób na ustalenie danych osobowych sprawcy naruszenia. Celem postępowania karnego, a zarazem jednym z podstawowych obowiązków ciążących na organach prowadzących postępowanie karne, jest wykrycie sprawcy przestępstwa i następnie pociągnięcie go do odpowiedzialności karnej. W sprawach z oskarżenia prywatnego, a takim jest postępowanie $\mathrm{z}$ art. 212 k.k., Policja na żądanie pokrzywdzonego przyjmuje ustną lub pisemną skargę i w razie potrzeby zabezpiecza dowody, po czym przesyła skargę do właściwego sądu (art. $488 \$ 1$ k.p.k.). W przypadku

\footnotetext{
${ }^{25}$ Wyrok Sądu Najwyższego z dnia 17 marca 2015 r. V KK 301/14, Lex nr 1663833

26 Tamże.

27 Tamże.
} 
wniesienia przez pokrzywdzonego skargi w rozumieniu art. $488 \$ 1$ k.p.k., w której nie określono sprawcy z imienia i nazwiska, obowiązkiem Policji jest podjęcie czynności zmierzających do ustalenia jego tożsamości (w ramach zabezpieczenia dowodów $)^{28}$. Z tego też względu skargi tej nie można traktować na równi z zawiadomieniem o przestępstwie ${ }^{29}$. Ustalenie zatem sprawcy jest dla postępowania karnego kluczowe, a jednocześnie nie ulega wątpliwości, że stosownie do treści art. 18 ust. 6 u.ś.u.d.e., organy prowadzące postępowanie karne są uprawnione do wystąpienia do service providera o udostępnienie danych osobowych sprawcy, a usługodawca ma obowiązek te dane na ich żądanie udostępnić. Dane osobowe sprawcy, które zostają ustalone na potrzeby postępowania karnego, osoba pokrzywdzona w następnej kolejności wykorzystuje dochodząc swoich praw na drodze postępowania cywilnego. W konsekwencji postępowanie karne zainicjowane może zostać jedynie w celu ustalenia danych osobowych sprawcy naruszenia dobra osobistego, co prowadzi do sytuacji, w której organy karne są wykorzystywane nie dla realizacji celów postępowania karnego, a w celu ustalenia danych osobowych naruszyciela na potrzeby postępowania cywilnego. Taka praktyka legła m.in. u podstaw wystosowania propozycji zmian do ustawy, wskazanej na wstępie. W uzasadnieniu projektu ustawy wskazano m.in., że "długotrwałość i nieefektywność procedury przewidzianej przez ustawę $z$ dnia 29 sierpnia 1997 r. o ochronie danych osobowych, powoduje, iż część osób w celu ustalenia danych osobowych sprawcy naruszenia korzysta obecnie z przepisów ustawy z dnia 6 czerwca 1997 r. - Kodeks postępowania karnego (Dz. U. poz. 555, z późn. zm.) dotyczących postępowania w sprawach z oskarżenia prywatnego. Możliwości wykorzystania tej drogi są jednak ograniczone, a ponadto instytucje procesu karnego zostały powołane do innych celów i nie powinny być wykorzystywane jako narzędzie do ustalania danych osobowych sprawcy naruszenia, w celu późniejszego wytoczenia przeciwko niemu procesu cywilnego" ${ }^{30}$. Fakt zwrócenia uwagi na tę praktykę przez projektodawców ustawy nowelizującej, świadczy o skali tego zjawiska.

Reasumując powyższe uwagi stwierdzić należy, że ustalenie danych osobowych sprawcy naruszenia dóbr osobistych celem skierowania przeciwko niemu powództwa o ich ochronę, jest możliwe także wówczas, gdy sprawca posłużył się pseudonimem. Może ono nastąpić na podstawie wniosku osoby dotkniętej naruszeniem lub organów państwowych na potrzeby prowadzonych przez nie postępowań (art. 18 ust. 6 u.ś.u.d.e., art. 6 lit. f RODO). Jednocześnie samodzielne uzyskanie tych danych przez osobę prywatną dotkniętą naruszeniem

${ }^{28}$ T. Razowski, A.Tomaszewski, O właściwym rozumieniu skargi o wszczęcie postępowania w sprawach o przestępstwa ścigane z oskarżenia prywatnego (art. $488 \$ 1$ k.p.k.), Prok. i Pr. 2005, $\mathrm{Nr} 6$, s. 153 i nast.

${ }^{29}$ Zob. T. Razowski, A.Tomaszewski, O właściwym rozumieniu..., s. 153 i nast.

${ }^{30}$ Uzasadnienie projektu ustawy, druk Sejmu VIII Kadencji Nr 1715. 
jest utrudnione i w praktyce często nieefektywne i długotrwałe. Trudności te zauważyli projektodawcy ustawy o zmianie ustawy - Kodeks postępowania cywilnego oraz ustawy Prawo telekomunikacyjne ${ }^{31}$ wskazując wyraźnie, że "celem ustawy jest wzmocnienie ochrony prawnej obywateli w zakresie ochrony dóbr osobistych, a w szczególności ułatwienie obywatelom dochodzenia roszczeń na drodze cywilnej w przypadkach naruszeń dóbr osobistych, do których dochodzi za pośrednictwem internetu" ${ }^{32}$. Z tego też względu zaproponowano, na wzór istniejącej w USA instytucji "ślepego pozwu" (ang. John Doe lawsuit), wprowadzenie także do polskiego systemu możliwości wytoczenia powództwa przeciwko osobie o nieustalonej tożsamości. Projektodawcy zaproponowali, aby w Kodeksie postępowania cywilnego dodać "Dział IX. Postępowanie w sprawach o ochronę dóbr osobistych przeciwko osobom o nieustalonej tożsamości”, w którym powód wnosiłby pozew bez wskazania danych osobowych pozwanego (proponowane brzmienie art. $505^{42} \$ 1$ k.p.c.). Przepisy tego działu miałyby znaleźć zastosowanie do spraw o ochronę dóbr osobistych, jeżeli do ich naruszenia doszło za pośrednictwem Internetu, a powód nie zna danych osobowych pozwanego, koniecznych do wniesienia pozwu (proponowane brzmienie art. $505^{40}$ k.p.c.). Ciężar ustalenia danych osobowych naruszyciela miał ciążyć na sądzie rozpoznającym sprawę, który zobowiązany byłby do zwrócenia się do operatora publicznej sieci telekomunikacyjnej lub dostawcy publicznie dostępnych usług telekomunikacyjnych o udostępnienie danych, o których mowa w art. 180c ustawy z dnia 16 lipca 2004 r. Prawo telekomunikacyjne, $w$ celu ustalenia danych osobowych pozwanego (proponowane brzmienie art. $505^{44} \$ 1$ i 2 k.p.c.). Takie rozwiązanie niewątpliwie ułatwiłoby osobie dotkniętej anonimowym wpisem dochodzenie swoich praw przeciwko naruszycielowi, a w konsekwencji także przyczyniłoby się do efektywniejszej ochrony dóbr osobistych przed naruszeniami w sieci.

\section{Bibliografia załącznikowa}

\section{Literatura}

A. Flores, C. James, Morality and ethics behind the screen: Young people's perspectives on digital life (w:) New Media \& Society, Volume: 15 issue: 6, s. 834-852, September 1, 2013

Ł. Jonak, Dlaczego boimy sięjednego procenta? O braku agresji w Internecie, [w:] Internetowa kultura obrażania?, K. Krejtz (red.), Interactive Advertising Bureau Polska, Szkoła Wyższa Psychologii Społecznej oraz Ośrodek Przetwarzania Informacji

T. Justyński, Nadużycie prawa w polskim prawie cywilnym, Kraków 2000

${ }^{31}$ Druk Sejmu VIII Kadencji Nr 1715.

${ }^{32}$ Uzasadnienie projektu ustawy, druk Sejmu VIII Kadencji Nr 1715. 
K. Klafkowska-Waśniowska, Komentarz do art. 18 ustawy o świadczeniu usług droga elektroniczną, (w:) D. Lubasz (red.), M. Namysłowska (red.), W. Chomiczewski, K. Klafkowska-Waśniowska, Świadczenie usług drogą elektroniczną oraz dostęp warunkowy. Komentarz do ustawy, LexisNexis 2011, Lex nr 334468

A. Kuźnicka, Egzekwowanie prawa autorskiego w Internecie a ochrona danych osobowych użytkowników, ZNUJ 2010, Nr 110, s. 109

T. Razowski, A.Tomaszewski, O właściwym rozumieniu skargi o wszczęcie postępowania w sprawach o przestępstwa ścigane z oskarżenia prywatnego (art. 488 § 1 k.p.k.), Prok. i Pr. 2005, Nr 6

A. Szpunar, Ochrona dóbr osobistych, PWN Warszawa 1979

A. Szpunar, Stosowanie art. 5 kodeksu cywilnego w sprawach o prawa stanu, PiP 1981, Nr 6

A. Rogacka-Łukasik, Naruszenie dóbr osobistych winternecie oraz ich ochrona na podstawie ustawy o świadczeniu usług droga elektronicznq, Roczniki Administracji i Prawa. Teoria i Praktyka, ROK XII, Sosnowiec 2012

P. Waglowski, Spam a prawo. Próba wskazania kierunków badawczych, Prawo i Ekonomia w Telekomunikacji 2003, nr 4

\section{Orzecznictwo}

Wyrok ETS z dnia 29 stycznia 2008 r., w sprawie Productores de Música de España (Promusicae) przeciwko Telefónica de. España SAU, C-275/06, Zb.Orz. (2008) I-271

Postanowienie ETS z dnia 19 lutego 2009 r. w sprawie LSG a Tele Telecommunication GmbH, C-557/07, ECR Zb. Orz. (2009) I-01227

Wyrok ETS z dnia 19 kwietnia 2012 r., w sprawie Bonnier Audio AB i inni przeciwko Perfect Communication Sweden $A B, C-461 / 10$, Lex 1131310.

Wyrok SN z dnia 19 września 1968 r., II CR 291/68, OSNC 1969, Nr 11, poz. 200

Wyrok Sądu Najwyższego z dnia 17 marca 2015 r. V KK 301/14, Lex nr 1663833.

Wyrok Sądu Najwyższego z dnia 30 września 2016 r., I CSK 598/15, LEX nr 2151458

Wyrok Sądu Apelacyjnego w Krakowie z dnia 21 marca 1995 r., I ACr 113/95 (w:) Dobra osobiste. Zbiór, wkładka 1995, Nr 3, poz. 22.

Wyrok Naczelnego Sądu Administracyjnego w Warszawie z dnia 10 listopada 2015 r., I OSK 685/14, LEX nr 1989980

Wyrok Naczelnego Sądu Administracyjnego w Warszawie z dnia 21 sierpnia 2013 r., I OSK 1666/12, LEX nr 1391700

Wyrok Naczelnego Sądu Administracyjnego w Warszawie z dnia 13 lutego 2014 r., I OSK 1641/12, LEX nr 149727

\section{Streszczenie}

Przedmiotem rozważań podjętych przez Autorów w niniejszym artykule jest problematyka prawna związana z możliwością dochodzenia roszczenia z tytułu naruszenia dóbr osobistych w Internecie od bezpośredniego sprawcy naruszenia przez pryzmat konieczności ustalenia danych osobowych naruszyciela. Omówiono możliwość złożenia wniosku o udostępnienie tych danych do service providera, uwzględniając zarówno stanowisko wyrażane przez ETS, jak i krajowe sądownictwo administracyjne. Zwrócono uwagę na fakt, że trudność w ustaleniu tych danych (przede wszystkim zgodnie z zapisami ustawy z dnia 18 lipca 2002 r. o świadczeniu usług drogą elektroniczną) skutkuje nieprawidłową praktyką inicjowania postępowania karnego, co z kolei powoduje obciążenie organów dochodzeniowych zadaniami nie służącymi celom procesu karnego a cywilnego. 
Słowa kluczowe: naruszenie dóbr osobistych, Internet, sprawca anonimowy, dane osobowe, service provider.

\section{Determining the personal data of the perpetrator unknown of the infringement of personal rights on the Internet in order to assert their protection in civil proceedings}

\section{Summary}

The subject of the considerations taken up by the authors in this article is the legal issues related to the possibility of pursuing a claim for infringement of personal rights on the Internet from the direct infringer through the prism of necessity to establish the personal data of the infringer unknown. The possibility of submitting an application for making this data available to the service provider was discussed, taking into account both the position expressed by the Court of Justice of the European Union and the national administrative courts. Attention was drawn to the fact that the difficulty in establishing these data (in accordance with the provisions of the Act of 18 July 2002 on the provision of electronic services) results in an incorrect practice of initiating criminal proceedings, which in turn causes the investigative authorities to be burdened with tasks that do not serve the purposes of the criminal trial but in fact civil cases.

Keywords: infringement of personal rights, Internet, infringer unknown, personal data, service provider. 